
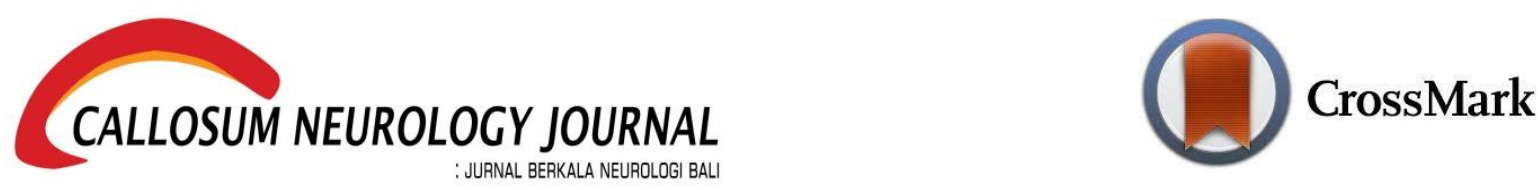

\title{
PERANAN IDARUCIZUMAB UNTUK MENETRALISIR EFEK ANTIKOAGULAN DABIGATRAN
}

Ida Bagus Kusuma Putra, Andreas Soejitno

Departemen Neurologi, FK Universitas Udayana/RSUP Sanglah, Denpasar, Bali, Indonesia

Diterima 01 Maret 2019

Disetujui 10 Maret 2019

Publikasi 1 September 2019

Korespondensi: andreas.soejitno@live.com
Putra, et al. 2019. Peranan Idarucizumab Untuk Menetralisir Efek Antikoagulan Dabigatran. Callosum Neurology Journal 2(3): 83-88. DOI: https://doi.org/10.29342/cnj.v2i3.61

\section{ABSTRAK}

Dabigatran etexilate (Pradaxa) telah disetujui oleh FDA dan Uni Eropa sebagai antikoagulan untuk mencegah stroke dan emboli sistemik pada pasien dengan atrial fibrilasi non-valvular dan satu atau lebih faktor risiko lain. Dabigatran etexilate merupakan bentuk inaktif (prodrug) dari dabigatran, inhibitor trombin direk. Namun demikian, seperti antikoagulan lain pada umumnya, penggunaan dabigatran tetap memiliki risiko terjadi perdarahan mengancam nyawa, walaupun jarang terjadi. Selain itu, pasien pengguna dabigatran kadang juga memerlukan tindakan pembedahan emergensi atau prosedur invasif lainnya yang memerlukan netralisasi efek antikoagulan dengan segera.
Pilihan terapeutik untuk menetralisir efek dabigatran meliputi penggunaan konsentrat kompleks protrombin, konsentrat kompleks protrombin yang teraktivasi, dan faktor VIla rekombinan, namun terdapat terapi spesifik berupa antibodi monoklonal yang menetralisir efek antikoagulasi dabigatran secara lebih akurat dan dapat diprediksi, berupa idarucizumab (Praxibind). Idarucizumab telah disetujui penggunaannya di berbagai negara, termasuk Amerika Serikat, Uni Eropa, Kanada, dan Australia. Kata Kunci: dabigatran, idarucizumab, antibodi monoklonal

\section{ABSTRACT}

Dabigatran etexilate (Pradaxa) has been approved by the FDA and the European Union as an anticoagulant to prevent stroke and systemic embolism in patients with non-valvular atrial fibrillation and one or more other risk factors. Dabigatran etexilate is an inactive form (prodrug) from dabigatran, a thrombin direct inhibitor. However, like other anticoagulants in general, the use of dabigatran still has the risk of life-threatening bleeding, although rare. In addition, patients with dabigatran sometimes also require emergency surgery or other invasive procedures that require neutralization of the anticoagulant effect immediately

Therapeutic options for neutralizing dabigatran effects include the use of prothrombin complex concentrates, activated prothrombin complex concentrates and recombinant factor VIla, but there are specific therapies in the form of monoclonal antibodies that neutralize dabigatran anticoagulation effects more accurately and predictably, idarucizumab (Praxibind). Idarucizumab has been approved for use in various countries, including the United States, European Union, Canada and Australia.

Keywords: dabigatran, idarucizumab, monoclonal antibody 


\section{Latar Belakang}

Antagonis vitamin $\mathrm{K}$ oral seperti warfarin telah lama menjadi obat pilihan untuk pencegahan stroke pada atrial fibrilasi. Namun penggunaan warfarin relatif sulit karena masalah interaksi obat-obat, obat-makanan, indeks terapeutik yang sempit, dan efek antikoagulan yang tidak dapat diprediksi. Seluruh masalah tersebut memerlukan pemantauan aktivitas koagulasi secara berkala. Antikoagulan oral antagonis nonvitamin $\mathrm{K}$ (NOAC) dirancang untuk mengatasi kelemahan warfarin tersebut dan memiliki awitan kerja cepat, efek yang menghilang dengan cepat (offset action), interaksi obat yang lebih jarang, dan tidak memerlukan pemantauan antikoagulan (Patel dkk, 2016). NOAC yang ada di pasaran saat ini meliputi apixaban, edoxaban, dan rivaroxaban, serta penghambat trombin (faktor Ila) direk dabigatran. ${ }^{1}$

Dabigatran etexilate merupakan obat prodrug molekul kecil dari dabigatran. Dabigatran merupakan inhibitor kompetitif trombin direk, poten, dan reversibel. Trombin merupakan serine protease yang bertanggungjawab dalam mengonversi fibrinogen menjadi fibrin pada kaskade koagulasi. Dabigatran menghambat trombin bebas maupun yang berikatan sehingga mencegah formasi trombus. In vitro, dabigatran menghambat trombin dengan pola dosis dependen. Dabigatran memiliki selektivitas tinggi terhadap trombin dengan rasio selektivitas $>700$ hingga $>10.000$ pada trombin dibandingkan serine protease lain pada kaskade koagulasi. $^{2}$

Berdasarkan studi RE-LY, dabigatran 110 dan $150 \mathrm{mg}$ dua kali sehari terbukti efektif mencegah stroke dan emboli sistemik pada pasien dengan AF non valvular dan risiko stroke. ${ }^{3}$ Dosis dabigatran terbukti non-inferior dibandingkan warfarin untuk mencegah stroke atau emboli sistemik. Namun dabigatran etexilate $150 \mathrm{mg}$ dua kali sehari terbukti superior dibandingkan warfarin dalam mencegah stroke atau emboli sistemik.

Kejadian seluruh stroke, stroke hemorhagik, dan stroke iskemik, stroke fatal dan non-fatal, dan kematian akibat vaskuler lebih rendah secara signifikan pada dabigatran $150 \mathrm{mg}$ dua kali sehari dibandingkan warfarin. Lebih lanjut, tidak terdapat perbedaan bermakna perihal kejadian infark miokardium, emboli paru, rawat inap dibandingkan warfarin pada dosis $150 \mathrm{mg}$, sementara dosis $110 \mathrm{mg}$ memiliki risiko perdarahan dua kali lebih rendah secara bermakna dibandingkan warfarin.

\section{Pembahasan}

\section{Farmakokinetik dan Farmakodinamik Idarucizumab}

Idarucizumab merupakan fragmen antibodi monoklonal yang berasal dari molekul isotipe imunoglobulin G1 yang berikatan dengan dabigatran dan mencegah efek antikoagulannya. Idarucizumab berikatan secara kuat dengan dabigatran (2,1 pmol/L), yakni sekitar 350 kali lebih kuat daripada ikatan antara trombin dengan dabigatran $(700 \mathrm{pmol} / \mathrm{L}) .{ }^{4}$ Dengan demikian, idarucizumab berikatan dengan dabigtran bebas, dabigatran yang telah berikatan dengan trombin, maupun metabolit glukoronida aktif dabigatran dengan rasio kompleks stoikiometri 1:1 dan menetralisir efek antikoagulan dabigatran. Dosis idarucizumab sebesar $5 \mathrm{~g}$ dapat menghambat aktivitas seluruh bentuk dabigatran (bentuk bebas, ikatan dengan protein, dan metabolit aktif). Dosis idarucizumab yang relatif besar disebabkan karena berat molekul idarucizumab yang lebih berat dibandingkan dengan dabigatran (47.800 vs. 472 $\mathrm{kDa})^{5}$

Idarucizumab bersifat spesifik dan hanya berikatan serta menetralisir dabigatran dan tidak memiliki efek terhadap antikoagulan tipe lain.

Idarucizumab mayoritas berada pada intravaskuler, sedangkan dabigatran dapat berada pada intravaskuler dan interstisiel. Pada saat idarucizumab berikatan dengan dabigatran di plasma, kadar dabigatran dalam plasma menurun, sehingga diikuti pula dengan perpindahan dabigatran dari interstisiel ke intravaskuler dan meningkatkan ikatan dengan idarucizumab. Proses tersebut berlanjut hingga seluruh dabigatran berikatan dengan idarucizumab.

\section{Studi Pre-Klinis Idarucizumab}

Studi pre-klinis menunjukkan bahwa idarucizumab menetralisir efek antikoagulan dabigatran dan menurunkan risiko perdarahan akibat trauma, berikut mortalitasnya. Pada mencit yang diberi dabigatran, idarucizumab 
terbukti dapat menormalkan waktu trombin, aPTT, dan perdarahan vena pada ekor mencit secara in vivo. ${ }^{4}$ Lebih lanjut, studi hewan coba yang diberikan dabigatran dan kemudian diberikan idarucizumab menunjukkan penurunan volume hematoma dibandingkan kontrol secara signifikan $(p<0,05)$ dan menurunkan mortalitas 7 hari dari 80 sampai $42 \%{ }^{6}$

Pada studi hewan coba babi dengan cedera tumpul (trauma tumpul hepar) yang diberikan dabigatran dosis tinggi, bolus idarucizumab dosis tunggal $(30,60$, atau $120 \mathrm{mg} / \mathrm{kg}$ ) menurunkan konsentrasi dabigatran bebas (yang tidak berikatan dengan trombin) sebesar 75,80 , dan 93\% secara berurutan (Grottke dkk, 2015). Idarucizumab menormalkan berbagai parameter tes koagulasi seperti aPTT, dTT, waktu pembekuan ecarin (ecarin clotting time/ECT), dan dabigatran-induced inhibition of endogenous thrombin potential (ETP) dan menurunkan kehilangan darah secara signifikan $(p<0,05)$ dibandingkan kontrol. Saat seluruh hewan coba kontrol yang menerima larutan saline mati, tingkat kesintasan kelompok yang menerima idarucizumab 60 dan $120 \mathrm{mg} / \mathrm{kg}$ adalah $100 \%$.

Lebih lanjut, idarucizumab menetralisir perubahan yang dipicu dabigatran perihal waktu trombin, aPTT, parameter tromboelastometri dan parameter generasi trombin (lag time, peak thrombin, dan ETP) secara ex vivo pada hewan coba babi dengan politrauma. ${ }^{7}$ Pada model tersebut, idarucizumab tampak lebih efektif dibandingkan konsentrat protrombin kompleks. Walaupun konsentrat protrombin kompleks (PCC) dapat menetralisir sebagian besar efek dabigatran, PCC tidak menormalisir aPTT dan cenderung bersifat pro-trombotik, kedua hal yang tidak dijumpai pada penggunaan idarucizumab. Lebih lanjut, idarucizumab dapat menurunkan tingkat kehilangan darah secara bermakna $(p<0,005)$, melebihi penggunaan PCC atau PCC teraktivasi. ${ }^{7}$ Secara in vitro, idarucizumab mampu menetralisir perubahan berurutan (Glund dkk, 2015). Pada seluruh kelompok dosis idarucizumab, dTT, ECT, aPTT, dan waktu trombin menurun lebih dari batas normal nilai teratas upper limit of normal/ULN) segera setelah infus idarucizumab dan ACT menurun dibawah kadar ULN 30 menit setelah yang dipicu oleh dabigatran pada platelet, deposisi fibrin pada pembuluh darah yang rusak, serta menormalisir produksi trombin dan parameter tromboelastometri pada darah manusia.

\section{Uji Keamanan Idarucizumab pada Manusia}

Pada studi klinis manusia fase I, idarucizumab tidak menunjukkan efek bermakna apabila tidak terdapat dabigatran pada subjek Kaukasia atau Jepang yang sehat. $^{8}$ Ketika idarucizumab diberikan pasca pemberian dabigatran, konsentrasi dabigatran bebas di dalam plasma menurun dan menetralisir efek antikoagulan. Pemberian idarucizumab dosis tunggal pada 1 jam (20 mg $-8 \mathrm{~g}$ ) atau 5 menit (1-4 g) tidak memberikan efek terhadap dTT, ECT, waktu trombin, aPTT, dan activated clotting time (ACT) atau pada ETP (biomarker protrombotik) pada subjek Kaukasia ( $n=110)$. Hasil serupa juga dijumpai pada subjek orang Jepang $(n=32)$. Lebih lanjut, kadar biomarker protrombotik (seperti produksi trombin, D-dimer dan fragmen protrombin 1.2 tidak berubah antara idarucizumab dan plasebo pada subjek Kaukasia dan Jepang. ${ }^{9}$

Pada subjek yang mendapat dabigatran, kadar dabigatran bebas dalam plasma menurun segera setelah pemberian infus idarucizumab. Sebagai contoh, pada sebuah studi, konsentrasi dabigatran menurun atau mendekati batas terbawah kuantifikasi (lower limit of quantification/LLOQ; $1 \mathrm{ng} / \mathrm{mL}$ ) setelah pemberian idarucizumab infus dosis tunggal selama 5 menit $(1,2$, atau $4 \mathrm{~g})$ atau dua infus serial berdurasi 5 menit ( $5 \mathrm{~g}$ dan 2,5 g) terpisah selama 1 jam, kadar dabigatran bebas dalam plasma tetap berada dibawah $5 \mathrm{ng} / \mathrm{mL}^{8}$

Idarucizumab memiliki efek langsung, komplit, dan bertahan dalam hal efek antikoagulan dabigatran pada subjek dewasa muda sehat. Pemberian dabigatran memperpanjang dTT, ECT, aPTT, waktu trombin, dan ACT sebesar $1,82,2,94,2,06,11$, dan 1,63 kali secara

infus. Rerata nilai dTT bertahan dibawah ULN selama 72 jam setelah pemberian idarucizumab $\geq 2$ g. Idarucizumab menurunkan dTT secara dosis-dependen, seperti diukur dengan rerata rasio area under the effect curve (AUEC) dari 2 
hingga 12 jam ( $\mathrm{AUEC}_{2-12}$ ) hingga $A U E C_{2-12}$ hari ke3.

Lebih lanjut idarucizumab dapat menetralisir efek dabigatran pada pria dan wanita yang berbeda kelompok usia dan derajat gangguan fungsi ginjal, mengindikasikan bahwa umur, jenis kelamin, dan fungsi ginjal tidak mempengaruhi normalisasi antikoagulan. ${ }^{9}$ Efek antikoagulan dabigatran kembali efektif saat dabigatran diberikan kembali dalam 24 jam setelah riwayat pemberian idarucizumab 2,5 atau $5 \mathrm{~g}$. Dosis kedua idarucizumab 2,5 g yang diberikan 2 bulan setelah dosis pertama dapat menetralisir dabigatran dengan pola yang sama. Idarucizumab dieliminasi secara cepat terutama oleh ginjal $(47 \mathrm{~mL} /$ menit) dengan waktu paruh awal 47 menit dan waktu paruh terminal 10,3 jam. Setelah pemberian idarucizumab $5 \mathrm{mg}$ secara intravena, sebanyak $32,1 \%$ dosis obat ditemukan pada urin subjek pada 6 jam pertama dan kadar obat kurang dari 1\% dalam 18 jam berikutnya. Dosis obat terutama dieliminasi melalui katabolisme protein, terutama oleh ginjal.

Karena idarucizumab terutama dieliminasi melalui ekskresi ginjal, eliminasi total idarucizumab mengalami penurunan pada pasien dengan gangguan fungsi ginjal, menyebabkan peningkatan paparan. Dibandingkan subjek sehat, paparan idarucizumab meningkat sebesar 26,78 , dan $199 \%$ pada pasien dengan gangguan fungsi ginjal ringan, sedang, dan berat. $^{5}$

\section{Efektivitas Klinis Idarucizumab}

Informasi perihal kemampuan idarucizumab dalam menetralisir efek samping dabigatran mayoritas diperoleh dari RE-VERSE AD, sebuah studi klinis prospektif fase 3 yang mengikutsertakan dua lengan, yakni subjek dengan perdarahan yang tidak terkontrol atau mengancam nyawa dan memerlukan netralisasi antikoagulan segera (grup A), serta subjek yang memerlukan tindakan pembedahan atau invasif lainnya yang bersifat emergensi dalam 8 jam ke depan yang memerlukan fungsi hemostasis yang baik (grup B). RE-VERSE AD menggunakan kriteria inklusi yang luas dan menyertakan subjek berusia lebih dari sama dengan 18 tahun tanpa batasan atas usia, pasien dengan trauma akut, dan pasien dengan harapan hidup terbatas. Seluruh subjek menerima idarucizumab $5 \mathrm{~g}$ yang diberikan dalam $50 \mathrm{~mL}$ infus intravena bolus, masing-masing mengandung 2,5 g idarucizumab yang diberikan terpisah maksimal 15 menit. ${ }^{10}$ Dosis $5 \mathrm{~g}$ dipilih untuk menetralisir efek dabigatran pada persentil 99 yang diperoleh dari uji klinis RE-LY. Dosis yang besar dan tetap mempermudah pemberian idarucizumab tanpa perlu mengukur konsentrasi dabigatran dan penyesuaian dosis idarucizumab. Luaran utama yang diharapkan adalah persentase netralisasi dabigatran maksimal yang dapat dicapai berdasarkan pengukuran dTT atau ECT di antara periode waktu infus pertama hingga 4 jam setelah infus kedua.

Mayoritas subjek menderita atrial fibrilasi dan menerima dabigatran untuk pencegahan stroke. Tipe perdarahan pada grup A meliputi perdarahan saluran cerna (39\%), intrakranial (35\%), traumatik (18\%), dan lainnya (22\%). Lebih lanjut sebanyak $31 \%$ dari subjek tidak stabil secara hemodinamik dan menderita kehilangan darah. Sementara itu indikasi tindakan invasif pada grup B meliputi fraktur (20,5\%), kolesistitis akut $(12,8 \%)$, dan kateterisasi akibat cedera ginjal akut (10,3\%).

Diantara subjek yang mengalami peningkatan dTT atau ECT pada awal studi, idarucizumab berhasil menetralisir efek dabigatran (dTT) pada 98 dan 93\% subjek di grup A dan B secara berurutan. Efek netralisasi dapat segera terlihat pasca infus pertama. Sementara itu ECT dapat dinormalisasi pada 89 dan $88 \%$ subjek di grup A dan B secara berurutan. Pada 12 dan 24 jam, dTT berada di bawah ULN pada 90 dan $81 \%$, sementara ECT berada di bawah ULN pada 72 dan $54 \%$ subjek di grup A dan B. Lebih lanjut, nilai aPTT dan waktu trombin juga mengalami normalisasi pada sebagian besar subjek di kedua grup.

Setelah pemberian idarucizumab, perdarahan berhasil dihentikan pada $97 \%$ subjek di grup A dalam 24 jam pertama (median 11,4 jam). Sementara itu, faal hemostasis normal saat operasi dilaporkan pada $92 \%$ subjek pada grup A.

\section{Tolerabilitas Idarucizumab}

Pada uji klinis, idarucizumab secara umum dapat ditoleransi dengan baik pada subjek sehat maupun pada subjek penerima dabigatran yang 
mengalami perdarahan tidak terkontrol atau memerlukan tindakan invasif segera. ${ }^{10}$ Pada analisis sementara REVERSE AD, efek samping yang paling sering muncul adalah hipokalemia (7\%), delirium (7\%), konstipasi (7\%), pireksia (6\%), dan pneumonia (6\%). Efek samping ringan berupa reaksi hipersensitivitas (pireksia, bronkospasme, hiperventilasi, kemerahan, pruritus) juga dilaporkan pada penggunaan idarucizumab. Sejumlah 26 pasien meninggal (21\%), 11 orang diantaranya meninggal setelah hari pertama pemberian idarucizumab, baik karena komplikasi, maupun karena komorbiditas.

Pada analisis 90 pasien uji RE-VERSE AD, efek samping serius terjadi pada $25 \%$ subjek (13/51) dengan perdarahan serius terjadi pada $21 \%$ subjek (8/39) memerlukan prosedur emergensi. Kejadian perdarahan meliputi perdarahan saluran cerna, infeksi luka pasca operasi, delirium, gagal fungsi ventrikel kanan, dan edema paru. ${ }^{3}$

Seperti antibodi monoklonal pada umumnya, idarucizumab memiliki potensi reaksi alergi (imunogenisitas). Reaksi silang terhadap idarucizumab terdeteksi pada 36 dari 283 subjek

\section{Daftar Rujukan}

1. Kirchhof $\mathrm{P}$, Benussi $\mathrm{S}$, Kotecha D, dkk. ESC guidelines for the management of atrial fibrillation developed in collaboration with EACTS. Eur Heart J 2016 doi:10.1093/eurheartj/ehw210.

2. Wienen $W$, Stassen JM, Priepke H, dkk. Invitro profile and ex vivo anticoagulant activity of the direct thrombin inhibitor dabigatran and its orally active prodrug, dabigatran etexilate. Thromb Haemost. 2007;98(1):155-62.

3. Connolly SJ, Ezekowitz MD, Yusuf S, dkk. Dabigatran versus warfarin in patients with atrial fibrillation. $\mathrm{N}$ Engl J Med. 2009;361(12):1139-51.

4. Schiele F, van Ryn J, Canada K, dkk. A specific antidote for dabigatran: functional and structural characterization. Blood 2013;121(18):3554-62.

5. Eikelboom JW, Quinlan DJ, Van Ryn J, dkk
$(12,7 \%)$. Mayoritas antibodi tersebut bertiter rendah dan $97 \%$ menunjukkan spesifisitas terhadap C-terminus dan bukan pada regio Fab lokasi ikatan dabigatran. Antibodi tersebut tidak berkaitan dengan farmakokinetik dan efek netralisasi dabigatran oleh idarucizumab dan tidak berkaitan dengan reaksi hipersensitivitas. Lebih lanjut, terdapat 9 dari 224 subjek (4\%) yang menunjukkan tanda-tanda resistensi terhadap idarucizumab, dengan target spesifik antibodi pada regio C-terminus (5 subjek), Fab (2 subjek), campuran (1 subjek), dan tidak diketahui (1 subjek). Setelah pemberian idarucizumab selama 2 bulan setelah dosis pertama, sebanyak 1 dari 6 subjek memiliki titer antibodi tanpa adanya reaksi hipersensitivitas.

\section{Simpulan}

Idarucizumab merupakan antibodi monoklonal yang bekerja secara spesifik untuk menetralisir efek antikoagulasi dabigatran. Idarucizumab memiliki awitan kerja cepat dan bersifat kerja panjang, serta efek samping minimal yang dapat dipertimbangkan untuk diberikan pada pasien dengan terapi dabigatran yang memerlukan reversal antikoagulan segera.

Idarucizumab: the antidote for reversal of dabigatran. Circulation. 2015;132(25):241222.

6. Na SY, Mracsko E, van Ryn J, dkk. Idarucizumab improves outcome in murine brain hemorrhage related to dabigatran. Ann Neurol. 2015;78(1):137-41.

7. Honickel M, Treutler S, van Ryn J, dkk. Reversal of dabigatran anticoagulation ex vivo: porcine study comparing prothrombin complex concentrates and idarucizumab. Thromb Haemost.2015;113(4):728-40.

8. Glund S, Stangier J, Schmohl M, dkk. Safety, tolerability, and efficacy of idarucizumab for the reversal of the anticoagulant effect of dabigatran in healthy male volunteers: a randomised, placebo-controlled, doubleblind phase 1 trial. Lancet2015;386(9994):680-90. 